\title{
Cutis marmorata telangiectatica congenital
}

\section{Cristina Isabel Pinho Resende, Catarina Araujo, Ana Paula Vieira, Celeste Brito}

Department of Dermatology and Venereology, Hospital de Braga, Braga, Portuga

\section{Correspondence to}

Dr Cristina Isabel Pinho Resende,

cristinapresende@gmail.com

\section{DESCRIPTION}

Cutis marmorata telangiectatica congenita (CMTC) is a skin vascular malformation of low flow, compromising venous and capillary vessels, of unknown origin, with about 300 cases described in the literature. ${ }^{1}{ }^{2}$ Clinical manifestations include a purple erythema, which is either generalised or more frequently localised over a limb, with hypotrophy of the affected limb. ${ }^{13}$

CMTC can be associated with extracutaneous findings in $20-80 \%$, including ocular and neurological abnormalities. ${ }^{2} 3$

CMTC resembles cutis marmorata, a common benign physiological response to cold in infants. However, unlike cutis marmorata, it does not resolve with warming of skin.

The authors report the case of CMTC in a 4-month-old female infant observed in the dermatology consultation by reticular erythema over the left superior limb, presented since birth, that did not disappear with local warming. On examination, she had reticular erythema over the left superior limb (figure 1) and hypotrophy of the same limb (figure 2). The circumferences of her left upper arm and right arm were 13.5 and $15.5 \mathrm{~cm}$, respectively. The circumferences of her left forearm and right forearm were 11 and $13 \mathrm{~cm}$, respectively (the measures were done $5 \mathrm{~cm}$ up and $5 \mathrm{~cm}$ down the olecranon process of the ulna).

The patient was checked by the department of ophthalmology and neurology to screen for associated anomalies, which were not detected.

Prognosis of CMTC is generally good, but it depends on the presence of associated

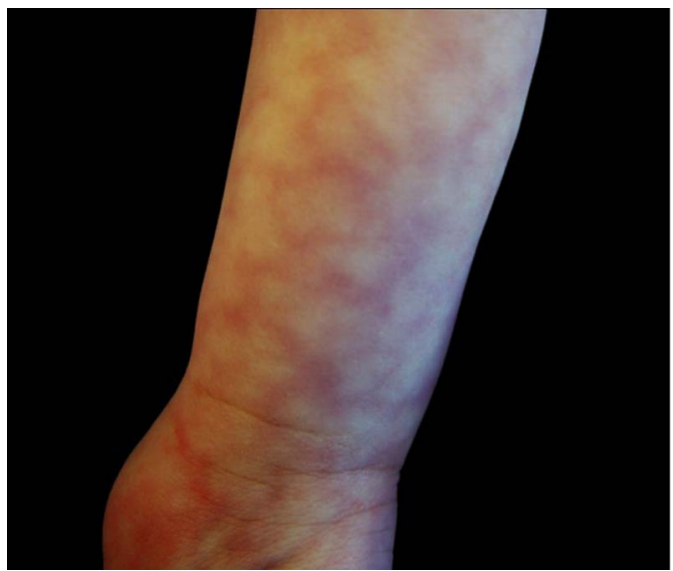

Figure 1 A reticular erythematous patch over the left superior limb.

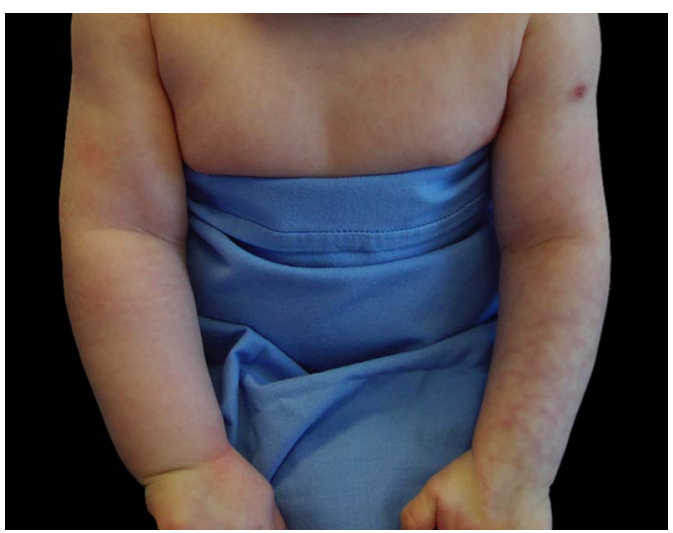

Figure 2 A reticular erythematous patch and atrophy over the left superior limb.

malformations. ${ }^{2} 3$ Skin lesions usually improve with age, but the limb asymmetry tends to persist. ${ }^{1}$

\section{Learning points}

- Cutis marmorata telangiectatica congenita (CMTC) is a rare skin vascular malformation, which resembles cutis marmorata, a common benign physiological response to cold in infants, but it does not resolve with warming of skin surface.

- Patients should be carefully evaluated for extracutaneous anomalies, including ocular and neurological abnormalities.

- Skin lesions of CMTC usually improve with age, but the limb asymmetry tends to persist.

Contributors CIPR contributed to the literature research, data collection and article writing. CA contributed to acquisition of the data. APV contributed to acquisition of the data, interpretation of the data and revision. CB contributed to acquisition of the data and revision

Competing interests None.

Patient consent Obtained.

Provenance and peer review Not commissioned; externally pee reviewed.

\section{REFERENCES}

1 Kienast AK, Hoeger PH. Cutis marmorata telangiectatica congenita: a prospective study of 27 cases and review of the literature with proposal of diagnostic criteria. Clin Exp Dermatol 2009;34:319-23.

2 Garzon MC, Schweiger E. Cutis marmorata telangiectatica congenita. Semin Cutan Med Surg 2004;23:99-106.

3 Levy R, Lam JM. Cutis marmorata telangiectatica congenita: a mimicker of a common disorder. CMAJ 2011;183:249-51.
Araujo C, Vieira AP, et al BMJ Case Rep Published online: [please include Day Month Year] doi:10.1136/ bcr-2013-200056 
Copyright 2013 BMJ Publishing Group. All rights reserved. For permission to reuse any of this content visit http://group.bmj.com/group/rights-licensing/permissions.

BMJ Case Report Fellows may re-use this article for personal use and teaching without any further permission.

Become a Fellow of BMJ Case Reports today and you can:

- Submit as many cases as you like

- Enjoy fast sympathetic peer review and rapid publication of accepted articles

- Access all the published articles

- Re-use any of the published material for personal use and teaching without further permission

For information on Institutional Fellowships contact consortiasales@bmjgroup.com

Visit casereports.bmj.com for more articles like this and to become a Fellow 